FACTA UNIVERSITATIS

Series: Economics and Organization Vol. 18, No 1, 2021, pp. 45 - 57

https://doi.org/10.22190/FUEO201102004S

Original Scientific Paper

\title{
SUSTAINABILITY RISK MANAGEMENT IN THE DIGITAL ECONOMY
}

\author{
UDC 005.334:501.131.1
}

\section{Jelena Z. Stanković, Evica Petrović, Jovica Stanković}

\author{
University of Niš, Faculty of Economics, Serbia
}

\begin{abstract}
The problem of sustainable development has become an imperative of globalization, which resolutely sets the request for companies to operate socially responsibly, i.e., to create value in a manner that is sustainable in the future by achieving economic, environmental and social goals. The wave of change, conditioned by digital transformation, is considered an opportunity, but also a challenge for the realization of the concept of sustainable development. Therefore, the aim of this paper is to consider the risks of sustainable business emerging from the implementation of ICT in the business process, with focus on the companies in the Republic of Serbia.
\end{abstract}

Key words: sustainability risks, digitalization, risk management, sustainable development

JEL Classification: Q01, Q56, L86, Q55, G32

\section{INTRODUCTION}

The increase in the number of risks associated with climate change and social disturbances, as well as the intensity of their effects, is estimated to reduce the gross domestic product of the global economy by up to $20 \%$ in the future (Stern \& Stern, 2007). In such business conditions, the problem of sustainable development is becoming increasingly important in corporate governance, due to the fact that companies are required to operate in a socially responsible way by achieving economic, environmental and social goals (Dangelico \& Pujari, 2010). Based on data on corporate social responsibility, it can be concluded that the number of companies that apply the principles of sustainable development in their business has increased. Thus, in 2011 , only $20 \%$ of the total number of companies

Received November 02, 2020 / Accepted February 17, 2021

Corresponding author: Jelena Z. Stanković

University of Niš, Faculty of Economics, Trg kralja Aleksandra 11, 18000 Niš, Serbia

E-mail: jelenas@eknfak.ni.ac.rs

(C) 2021 by University of Niš, Serbia | Creative Commons Licence: CC BY-NC-ND 
included in the S\&P 500 index basket published reports on sustainable operations, while in 2016 their number increased to $81 \%$ (Coppola, 2016).

The application of information and communication technologies (ICT) can provide solutions to many existing business challenges, such as shortening innovation cycles, increasing volatility and competitiveness in a dynamic business environment (Kagermann, 2015). However, if the importance of the digitization process for human life and work is taken into account, it can be concluded that this process will be crucial for achieving a long-term balance between social development and the environment (Souter et al., 2010). As the concept of sustainable development cannot be achieved without global communication and knowledge exchange (MacLean et al., 2007), business digitalization can be an opportunity to overcome development constraints, but also a serious risk factor for sustainable development, because the effects of Industry 4.0 on sustainability are still uncertain (Birkel et al., 2019). Due to the fact that 8 of the 10 most important business risks are directly related to the environmental and social problems (Schulte \& Hallstedt, 2017), risk management is a key factor for integrating the principles of sustainable development into business operations (Schulte \& Hallstedt, 2018). Thus, the aim of this paper is to consider the risks of sustainable business, arising from the implementation of ICT in the business process. Moreover, the application of ICT in companies in the Republic of Serbia for achieving the goals of sustainable business is assessed. According to this, the paper is structured in the following way: the second part describes the impact of ICT on socially responsible business, the third part explains the risks of sustainable development in the digital economy and opportunities for their integration into existing risk management frameworks. In order to access the risks of business digital transformation in the Republic of Serbia, a SWOT analysis of the application of ICT in companies in Serbia is presented in the fourth part of the paper. In the conclusion, the potential effects of the synergy of the digital economy and socially responsible business are presented, as well as the limitations of the existing application of ICT, especially in companies in the Republic of Serbia.

\section{SOCIALly RESPONSIBLE BUSINESS IN CONDITIONS OF DigitALIZATION}

The technological development of modern civilization has reached the stage of meeting different development goals, and the tendency to maintain the traditional model of economic growth leads to a conflict between economic and environmental goals. The combination of multiple pressures, such as continuous population growth, changes in consumption patterns and climate change, leads to a reduction of limited resources such as food, water, energy and materials, below the critical limit. Therefore, the concept of sustainable development has been gradually expanding by connecting sociology, economy and ecology. The focus of interest is on a complex, multidimensional ecosocial system, which provides basic services to society, such as food, drinking water, energy, and whose key components are environmental and social subsystems.

The complex and dynamic process of economic development has initiated a number of structural changes in the economy, both locally and globally. These changes include changes in the structure of demand and production, changes in the professional and qualification structure of the workforce, foreign trade and finance. The main characteristic of these changes is that they are not realized immediately, but in a long period of time through economic crises, transformations and improvements. As a result, there is an enormous increase in the impact of 
human activities on the ecological subsystem and the ecosocial system as a whole, but also the emergence of risks. Digitalization, as one of the biggest drivers of change in the 21st century, has completely changed the concept of development of the global economy and society, putting in the forefront the potential of ICT and the challenges of environmental sustainability (Ciocoiu, 2011).

The process of digitalization, as a process of connecting people and things and continuous convergence of the real and virtual world based on ICT, has had such a great impact on the ecosocial system that it has caused a re-examination of the basic structures of this system. Information and communication technologies have a dominant role in redefining products, processes, organizational structure and business models in many economic activities. Digital transformation can be defined as the expanded use of modern information technologies, such as analytics, mobile devices, social networks or smart integrated devices, as well as the advanced use of traditional technologies, such as ERP, to improve business (Westerman et al., 2014). This great wave of change is considered an opportunity, but also a challenge to achieve the United Nations Sustainable Development Goals (SDG), especially when it comes to reducing various forms of inequality, ensuring decent work and responsible production and consumption. Implementation in various spheres and the development of digital technologies create unique opportunities for improving social and environmental well-being, and further enhancing global living standards while preserving and improving the environment for future generations (Linkov et al., 2018). However, its impact on sustainable development is still not possible to assess reliably, although digitalization is expected to transform the economy, as well as society, in terms of economic, environmental and social performance (Muller et al., 2018). The classification of possible impacts of ICT on sustainable development depends on the level of development and application of information technologies in one community and is shown in Table 1.

Table 1 Classification of the impact of ICT on sustainable development

\begin{tabular}{|c|c|c|}
\hline Order of effects & Impact & $\begin{array}{l}\text { Direction of } \\
\text { action }\end{array}$ \\
\hline $\begin{array}{l}\text { First order effects: } \\
\text { production and } \\
\text { application of ICT }\end{array}$ & $\begin{array}{l}\text { Increased level of pollution and energy consumption } \\
\text { necessary for the production and application of ICT, as } \\
\text { well as for its disposal after use. }\end{array}$ & Negative \\
\hline $\begin{array}{l}\text { Second order effects: } \\
\text { use of ICT in order to } \\
\text { reduce energy / water } \\
\text { consumption, reduce } \\
\text { pollution }\end{array}$ & $\begin{array}{l}\text { Optimization of production processes and unsustainable } \\
\text { consumption due to the application of ICT (e.g. reduction } \\
\text { of energy consumption using various applications). }\end{array}$ & $\begin{array}{l}\text { Mostly } \\
\text { positive }\end{array}$ \\
\hline $\begin{array}{l}\text { Third order effects: } \\
\text { change of life habits }\end{array}$ & $\begin{array}{l}\text { The cumulative medium- to long-term impact that the use } \\
\text { of ICT can have by large numbers of people (e.g., } \\
\text { teleworking instead of traveling). }\end{array}$ & Positive \\
\hline Fourth order effects & $\begin{array}{l}\text { Improving overall social decision-making capacities and } \\
\text { measuring their impact in the field of real-time sustainable } \\
\text { development policy implementation. }\end{array}$ & Positive \\
\hline
\end{tabular}

Current research studies are devoted mainly to the technical challenges of implementing the Industry 4.0 concept (Liao et al., 2017), while the analysis of the risks associated with it has not yet been systematically described in the scientific literature. Isolated risk observation 
does not contribute to the detection of interdependencies that exist between the risks of traditional and digital business, which can cause a decrease in profit or reallocation of business due to loss of comparative advantages of companies that do not achieve adequate ICT implementation in the existing business model (Ghanbari et al., 2017). The transformation of the organization of the company can be further slowed down by social risks, such as requirements for retraining of employees or termination of jobs, especially for simple and routine operations, which are replaced by automated processes (Kazancoglu \& Ozkan-Ozen, 2018). Therefore, in the continuation of the paper, the changed effect of basic and additional business risks conditioned by the application of ICT in business will be explained.

\section{RISKS OF SUSTAINABLE BUSINESS IN THE DIGITAL ECONOMY}

Digitalization of management process, supported by comprehensive data analysis, advanced decision-making algorithms, and artificial intelligence, affects all three dimensions of sustainability (Kiel et al., 2017). However, in addition, the technical aspects of the implementation of the Industry 4.0 concept have opened up a number of questions regarding technical and regulatory requirements (Müller \& Voigt, 2018), which, if not adequately regulated, can become risk factors (Fig. 1).

Economic risks of ICT implementation in business operations affect the achievement of business results. Considering the complexity of information technology, the high value of investments, both in equipment and in employees, can be identified as one of the basic economic risks (Birkel et al., 2019). Due to the inability to accurately assess the economic life of the implemented technology, as well as the uncertainty regarding cash flow planning in the long run, decisions on the realization of these business ventures are very often classified in the group of those that require a careful assessment of the beginning of the investment period (Raj et al., 2020). Actually, investing in ICT in the mature phase of development, may cause smaller investments, but it does not provide the company with the expected comparative advantage. On the other hand, investments in underdeveloped technologies carry an additional risk of choosing the wrong technological solutions, which will not provide the company with the desired competitive position in the market. As an additional aspect of the impact of ICT on economic risks, the emergence of new business models can be pointed out, such as business cooperation through platforms (Kagerman, 2015), which, in addition to being an additional instrument for increasing business value, also creates the so-called risk of cannibalization of existing business models.

The implementation of digital technologies in business practice leads to the emergence of numerous environmental risks. The first effects of the use of ICT are mostly negative and relate to the excessive use of energy and a large quantity of raw materials for the production of equipment (Stock et al., 2018). Excessive use of energy is the result of the complex work process, especially the usage of additional services in data processing. Environmental pollution can be caused by inadequate disposal of equipment after use since for the most of the technology materials recycling processes are not available or are unprofitable to conduct (Behrendt, 2018). Despite significant efforts to reuse or adapt existing plants and equipment, this is not possible in most cases when more advanced technical and technological solutions have appeared in order to reduce costs and resources. The complexity of new technologies and the required capacities for their implementation 
limit the possibilities for using the existing capacities of the company. In addition, there may be an increase in the amount of waste due to mass personalization of products (Wang et al., 2017), which highlights the negative effects of the application of ICT in business and in the mature stages of its implementation.

The integration of digital technologies into the business process inevitably imposes the need for new competencies of employees, especially in terms of using ICT, reducing the number of business activities, but also increasing the flexibility of work organization, which can create additional pressures on the existing social tension (Schwab, 2017). In other words, employees are expected to have qualifications and skills to use advanced tools and technologies, as well as to be able to solve problems and perform multiple work tasks simultaneously in a complex environment (Bonekamp \& Sure, 2015). Such requirements often create a stressful work environment in which employees do not understand the role of advanced technologies in work, and often do not accept the changes that business modernization requires, despite additional training and education. In extreme situations, companies decide to relocate their business facilities, which increases unemployment and deepens the problem of social inequality.

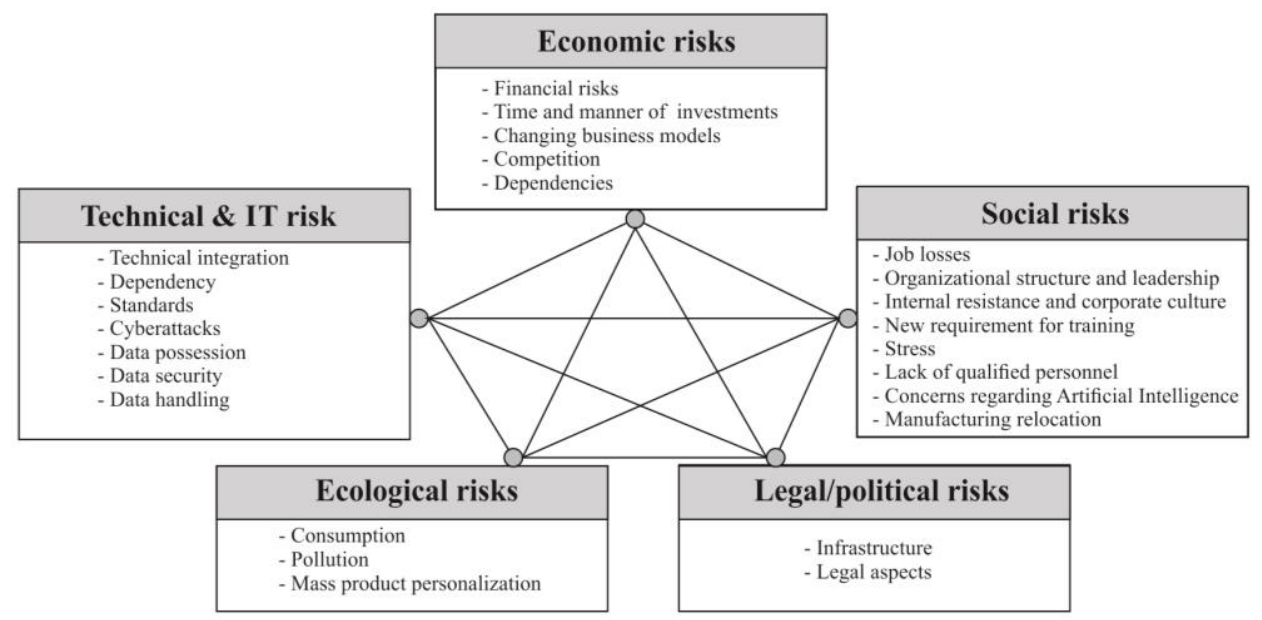

Fig. 1 ICT risks of sustainable development and their interdependence Source: Birkel et al. (2019)

A specific group of sustainability risks in the digital economy is represented by the risks of technical integration of the concept of digitalization into the business of the company (Kagermann, 2015). An integrated approach to business can have great potential for the growth and development of companies, but it is conditioned by a high level of complexity in implementation. This way of doing business becomes too dependent on technology, so the failure of software or systems can lead to a break in the entire value chain. Vertical and horizontal integration of business through ICT opens the business system to various external influences, and makes it vulnerable to cyber-attacks, but also calls into question the protection of data and the way they are used. Therefore, at the national level, it is necessary to have an adequate infrastructure, which will support the implementation of advanced ICT in business (Raj et al., 2020), and the globalization of business implies a high level of standardization 
(Schwab, 2017). Mass digitalization of business opens numerous problems, such as data protection, determining working hours, but also the protection and safety of employees at work, which is why the impact of advanced technologies on sustainability needs to be considered in terms of regulatory risks.

In accordance with these risks, there is a change in the role and importance of enterprise risk management in modern business conditions in a way that the long-term sustainability of business is closely linked to enterprise risk management (ERM). In such circumstances, the triple bottom line becomes a mandatory framework for measuring the results of socially responsible business. Companies that focus on socially responsible business are primarily engaged in activities that avoid future business problems, but also society, as a whole, is protected from potentially harmful effects of business operations (Godfrey et al., 2009). The fact is that these risks may have an impact on firm performance in the long run, but the effects of their manifestation cannot yet be adequately assessed, nor the link between long-term and short-term effects of sustainability risks and business risks (Bromiley et al., 2015). This situation is a consequence of the inconsistency of the way of integrating the concept of sustainable development into the existing framework of corporate governance and ERM. In other words, the requirement for corporate social responsibility can be seen as a specific business goal of the company (Saardchom, 2013) or existing business goals can be seen through the perspective of corporate social responsibility (Faris et al., 2013). The chosen aspect of the integration of the principles of sustainable development into the business will also affect the way of integrating sustainability risk into the ERM framework. ERM frameworks should be adapted to the new requirements for sustainability by including the concept of sustainability in all phases of risk management (Saardchom, 2013). Defining an adequate risk management framework enables companies to comprehensively and systematically assess, control, use, finance and monitor financial, strategic and operational risks, which in the short and long term may affect the interests of stakeholders.

In order to incorporate the principles of corporate social responsibility into the strategic management process, it is necessary to be aware of the risks of sustainability when performing all business activities - from daily, operational business to investment decision-making. The process of business digitalization goes beyond the digitalization of resources and involves the transformation of key business activities, products and processes, leading to modified or completely new business models, so the implementation of this process requires an appropriate strategy (Bharadwaj et al., 2013). In order to formulate and implement a digital transformation strategy, companies must consider: the use of technology, changes in value creation, structural changes and financial aspects of this process. When it comes to the external environment, market conditions, competition, technological trends, regulatory requirements, climate change, country risks and political risks can be considered the key factors of business success and sustainability, but also the conditions and method of financing, needs and requirements of external stakeholders and all other external influences and risks associated with them. The complexity of the company in terms of its size, number of organizational units, level of vertical integration, internal regulations, as well as the existing business strategy can be considered the internal factors that affect ERM in terms of digitalization and sustainability of the company. Therefore, in the following part of the paper the main risks of digitalization in the Republic of Serbia will be assessed using SWOT analysis. 


\section{RISKS OF DIGITALIZATION IN THE REPUBLIC OF SERBIA}

The ICT sector in Serbia offers potential for sustainable development. In 2017, the ICT sector participated with $4.42 \%$ in the creation of GDP (Eurostat Database), while in the same period, EUR 768 million (NBS Database) was generated from the export of ICT services. However, the application of ICT is still not in the function of sustainable development and increasing competitiveness. In the Republic of Serbia, $100 \%$ of companies have Internet connection, $84.4 \%$ of companies have a website, but only $27.9 \%$ of companies sell products or services online (SORS, 2020). Moreover, the largest number of companies (over 50\%) made less than $25 \%$ of profit through the online sales. This situation, as well as the fact that only $23 \%$ of companies use CRM to manage customer information, indicates that companies in Serbia do not sufficiently use the potential of the ICT sector. The impact of digitalization on sustainable development in the Republic of Serbia will be assessed by analyzing two indices: The Network Readiness Index and the Sustainable Development Index.

The Network Readiness Index (NRI) is a composite index that comprehensively assesses how society and the economy influence the development and application of information and communication technology. In order to adequately assess the impact of ICT on the development of society and the economy, NRI has changed its structure since 2002, when it was first presented to the public. Thus, in 2019 the index was significantly revised and improved. Data for the Republic of Serbia in comparison with the surrounding countries are higher, and a growing trend can be observed during the observed period (2009 - 2015), but not as high as in the EU Member States (Table 2).

Table 2 Descriptive statistics of NRI and SDI indicators in the period $2009-2015$ in the Republic of Serbia and neighboring countries

\begin{tabular}{|c|c|c|c|c|c|c|c|c|c|c|c|c|}
\hline & \multicolumn{2}{|c|}{ Serbia } & \multicolumn{2}{|c|}{$\begin{array}{c}\text { North } \\
\text { Macedonia }\end{array}$} & \multicolumn{2}{|c|}{ Bulgaria } & \multicolumn{2}{|c|}{ Croatia } & \multicolumn{2}{|c|}{$\begin{array}{c}\text { Bosnia and } \\
\text { Herzegovina }\end{array}$} & \multicolumn{2}{|c|}{ Albania } \\
\hline & NRI & SDI & NRI & SDI & NRI & SDI & NRI & SDI & NRI & SDI & NRI & SDI \\
\hline Min & 3,51 & 0,40 & 3,64 & 0,71 & 3,66 & 0,76 & 3,91 & 0,70 & 3,07 & 0,72 & 3,23 & 0,78 \\
\hline Max & 4,00 & 0,68 & 4,40 & 0,74 & 4,00 & 0,78 & 4,34 & 0,75 & 3,99 & 0,74 & 3,89 & 0,81 \\
\hline Mean & 3,70 & 0,52 & 3,93 & 0,72 & 3,85 & 0,77 & 4,13 & 0,73 & 3,50 & 0,73 & 3,58 & 0,80 \\
\hline St. Dev. & 0,18 & 0,10 & 0,28 & 0,01 & 0,11 & 0,01 & 0,17 & 0,02 & 0,37 & 0,01 & 0,25 & 0,01 \\
\hline
\end{tabular}

Source: Authors' calculation

On the other hand, if the level of Sustainable Development Index (SDI) is observed, it can be concluded that in the observed period $(2009$ - 2015) the Republic of Serbia was the least ecologically efficient in the process of human development (Table 2). Contrary to expectations, the value of SDI decreased during the period, so that the value of SDI fell from 0.69 in 2009 to 0.40 in 2015 (Fig. 2).

Spearman's rank correlation coefficient was calculated and its significance was tested in order to examine the interdependence between variations in NRI and SDI values in the Republic of Serbia. This indicator belongs to the category of nonparametric indicators and represents a nonparametric analogy of the simple linear correlation coefficient. Since the calculation of Spearman's rank correlation coefficient does not require the fulfillment of assumptions related to data distribution, its application is considered adequate in this case. 


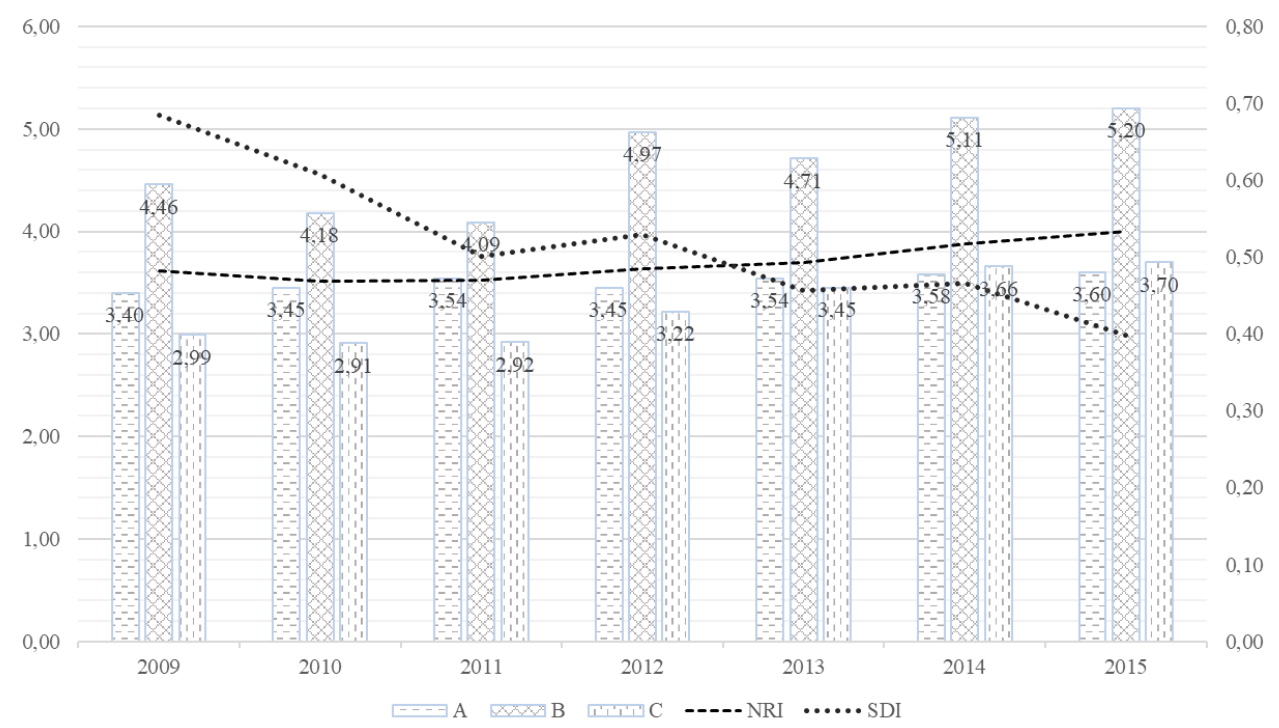

Fig. 2 NRI and its sub-indices scores and SDI scores for the Republic of Serbia Source: Authors' presentation

Table 3 Spearman's correlation coefficient values by indices and their sub-indices

\begin{tabular}{lccccc}
\hline & NRI & A: Environment & B: Readiness & C: Usage & SDI \\
\hline NRI & 1.00 & 0.73 & $\mathbf{0 . 9 3}^{*}$ & $\mathbf{0 . 9 9}^{*}$ & $\mathbf{- 0 . 7 9}^{*}$ \\
A: Environment & 0.73 & 1.00 & 0.58 & 0.73 & $\mathbf{- 0 . 9 3}^{*}$ \\
B: Readiness & $\mathbf{0 . 9 3}^{*}$ & 0.58 & 1.00 & $\mathbf{0 . 9 3}^{*}$ & -0.61 \\
C: Usage & $\mathbf{0 . 9 9}^{*}$ & 0.73 & $\mathbf{0 . 9 3}^{*}$ & 1.00 & $\mathbf{- 0 . 7 9}^{*}$ \\
SDI & $\mathbf{- 0 . 7 9 *}^{*}$ & $\mathbf{- 0 . 9 3}^{*}$ & -0.61 & $\mathbf{- 0 . 7 9}^{*}$ & 1.00 \\
\hline
\end{tabular}

*statistically significant correlation with $p$-value less than 0.05

Source: Authors' calculation

The calculated values of Spearman's rank correlation coefficient between variations in the estimates of NRI and its sub-indices and SDI, shown in Table 3, indicate the existence of a strong negative correlation, which is at the same time statistically significant. The value of the correlation coefficient between NRI and SDI is -0.79 and is statistically significant. The high values of Spearman's correlation coefficient between SDI and the NRI sub-indices Environment and Usage indicate a strong degree of indirect agreement in variations in the capacity of the environment and the use of ICT with the assessment of sustainable development in the Republic of Serbia. Specifically, the constant increase in the value of NRI scores is not sufficiently in accordance with the changes in SDI values.

Due to the adoption of Agenda 2030 and the Sustainable Development Goals in 2015, the method of calculating SDI has changed significantly, and during 2019 and 2020, the NRI index included for the first time the impact of ICT on sustainable development. Having in mind the mentioned risks of digitalization for sustainable development, the potential impacts of ICT on sustainable development in the Republic of Serbia were assessed using SWOT analysis. In this case, the assessments of the most important 
constituents of the NRI for the Republic of Serbia and their rank in relation to the score of the related sub-pillar, as well as in relation to the average score for the EU and countries of the same level of development were discussed. In accordance with the chosen method of assessment, the main weaknesses of Industry 4.0 and threats that could potentially slow down the achievement of the Sustainable Development Goals of the economy of the Republic of Serbia have been identified (Table 4).

If economic risks are observed, it can be concluded that insufficient investment is one of the basic weaknesses of companies in the Republic of Serbia. Digital technologies in the form of e-services, robotics or process management solutions can help companies achieve their business goals in the SDG context. However, investments of Serbian companies in the development of the ICT are very modest - only $2.06 \%$ of total investments in research and development relate to programming, consulting and related activities (Eurostat Database). Specifically, only $18.6 \%$ of companies pay for the Cloud services (RZS, 2020).

Table 4 SWOT analysis of the ICT risks and opportunities in the Republic of Serbia

\begin{tabular}{|c|c|}
\hline $\begin{array}{l}\text { Strengths } \\
\text { - Large number of firms having own } \\
\text { website } \\
\text { - Secured access to website } \\
\text { - Quality of e-Government services } \\
\text { - Accessibility, quality and relevance } \\
\text { of government websites }\end{array}$ & $\begin{array}{l}\text { Weaknesses } \\
\text { - Insufficient investment in and adoption of AI, } \\
\text { robotics, applications and websites for e-commerce, } \\
\text { big data analytics and Cloud computing } \\
\text { - Low value of purchased or leased computer software } \\
\text { - Inadequate computer literacy skills of employees } \\
\text { - Low level of mobile and e-business usage }\end{array}$ \\
\hline $\begin{array}{l}\text { Opportunities } \\
\text { - High R\&D expenditure in ICT by } \\
\text { governments and higher education } \\
\text { - Internet access and usage } \\
\text { - Fixed-broadband access } \\
\text { - Wide area coverage for Mobile } \\
\text { network access (4G) } \\
\text { - Regulatory and legal framework } \\
\text { for ICT } \\
\text { - Satisfactory legal protection of } \\
\text { Internet privacy }\end{array}$ & $\begin{array}{l}\text { Threats } \\
\text { - Low availability of government published open data } \\
\text { - Cybersecurity risks } \\
\text { - Low level of usage of e-Bank and m-Bank services, } \\
\text { especially in rural areas } \\
\text { - Inadequate policy and regulatory environment for } \\
\text { private sector development } \\
\text { - Slow policy and regulatory adaptability to disruptive } \\
\text { technologies } \\
\text { - Unsatisfactory legal framework for e-commerce } \\
\text { - Internet usage gender inequality } \\
\text { - Low level of environment monitoring }\end{array}$ \\
\hline
\end{tabular}

Source: Authors' elaboration according to Dutta and Lanvin (2020)

In regards to social risks, companies are burdened by the lack of basic ICT skills of employees, but also by the lack of permanently employed ICT experts. Only $19.3 \%$ of companies in Serbia permanently employ the ICT experts, while $14.6 \%$ provide ICT training for their employees and 56.6\% outsource ICT services (SORS, 2020). Low level of investments in employee training prevents better exploitation of available ICT capacities and slows down their integration into business models of companies. However, demand for qualified ICT experts in companies is high, since $43.7 \%$ of companies have unsuccessfully tried to employ ICT experts. The main obstacles for ICT experts' engagement are the lack of relevant experience $(71.4 \%)$, the lack for adequate qualifications $(65.6 \%)$, as well as high expectations regarding salaries (28.6\%) (SORS, 2020). Considering the low level of robots' usage - only $3 \%$ of companies use some type of robots in their business 
(Eurostat Database), it can be concluded that there is still no significant risk of job losses nor organization structure changes.

ICT infrastructure and legal regulations in the field of ICT provide a solid basis for the development of Industry 4.0 in the Republic of Serbia. However, the legislation does not sufficiently follow the specific areas of ICT application and does not adapt quickly enough to the changes that have occurred. Specifically, the weakest component of ICT legislative environment is the e-commerce legislation (Serbia's rank 77/134) and the adaptability of current legislative to emerging technologies (Serbia's rank 72/134) (Dutta \& Lanvin, 2020). This can be an obstacle to the development of e-business and the use of e-banking and $\mathrm{m}$ banking services, as well as significant change of existing business models.

The technical risks that companies in the Republic of Serbia face are mainly related to the availability of open data, data security and the implementation of Cloud solutions. Low availability of government published open data places Serbia to $65^{\text {th }}$ place out of 134, while cybersecurity risks rank is 60/134 (Dutta \& Lanvin, 2020). Thus, very small number of companies uses Big Data analysis - only $2 \%$ of companies in the Republic of Serbia comparing to the $13 \%$ of companies in the EU (Eurostat Database).

On the other hand, the contribution of ICT to the environment in the Republic of Serbia cannot be reliably assessed, because despite the fact that the application of ICT should contribute to improving environmental planning, natural disaster management and increased energy efficiency, environmental monitoring in the Republic of Serbia is very low and this information is usually not available. Instead, the most important contribution of ICT to SDG is observed for sustainability of cities and communities (41/134), quality education (45/134) and gender equality (53/134), while the contribution to achieving goals of affordable and clean energy is rather low (109/134), as well as good health and well-being (88/134) (Dutta \& Lanvin, 2020).

\section{CONCLUSION}

The company's business has changed significantly in recent decades. Companies operating in modern business conditions are directed to socially responsible business, which implies progress in terms of economic prosperity, environmental quality and social justice. Technical and technological changes, which have influenced knowledge and networks to play a greater role in economic development than capital, have led to the emergence of the concept of a sustainable digital economy as a solution to environmental and social problems. The synergetic effects of the digital economy and sustainable development have been recognized in developed economies. Besides this, based on experience, it can be concluded that ICT can support sustainable development in the following ways (IISD, 2010):

- reducing the direct effects of production, distribution, use and disposal of equipment on the environment by improving energy efficiency, using energy from renewable sources, reducing the use of toxic materials and improving recycling and waste disposal. ICTs are used to optimize the operations, thus increasing their efficiency while reducing pollution and resource consumption.

- increasing the effects of the ICT usage on sustainable development through improving the efficiency of production, distribution and consumption of goods and services. Complete or partial dematerialization of products and services enables the creation of their virtual 
substitutes, the production and use of which can significantly reduce emissions and energy use.

- supporting systemic effects resulting from changes in the behavior, affinities and value systems of individuals as citizens and consumers; changes in economic and social structures and political processes. ICT is used in the visualization and communication of information relevant to sustainable development, such as the use of energy, water or CO2 emissions, which is a prerequisite for the application of the principles of sustainable development.

Although countries have recognized the potential of combining the digital economy and the principles of sustainable development, a large number of companies still do not consider the integration of sustainability principles to be essential for their business (Ernst \& Young, 2017) and view these requirements exclusively from a risk management perspective. Analysis of the NRI and SDI index imply that Serbian companies do not apply ICT in the context of achieving SDGs. Companies confront many ICT risks, mainly regarding ICT skilled employees and financial means for investment in ICT. Moreover, legislative does not regulate the specific areas of ICT application and does not adapt quickly enough to the dynamics of digital economy decreasing the potential of ICT for sustainable development.

However, effective sustainability risk management implies adequate integration of these risks into existing risk management frameworks, but there are some limitations in practical application (Schulte \& Hallstedt, 2017). Unlike traditional risks, these risks have certain properties, such as the dynamics of change, qualitative assessment of the effects, pronounced uncertainty of manifestation. According to the available reports, the effects of most ICT risks on the economy are not available. In addition, there is no consensus on the definition of sustainable development, which prevents the creation of a clear risk management strategy, obscures accountability and prevents the establishment of an interdependence between costs and benefits. All this points to the insufficient maturity of the ERM to manage the risks of sustainable development.

Acknowledgement: The paper is a part of the research done with the support of the Erasmus+ Programme of the European Union within the project no. 611831-EPP-1-2019-1-RS-EPPJMOMODULE.

\section{REFERENCES}

Behrendt, S. (2018). „Recycling von Technologiemetallen “Transformationsfeldanalyse im Rahmen des Projektes „Evolution2Green-Transformationspfade zu einer Green Economy “Institut für Zukunftsstudien und Technologiebewertung.

Bharadwaj, A., El Sawy, O. A., Pavlou, P. A., \& Venkatraman, N. (2013). Digital business strategy: toward a next generation of insights. MIS quarterly, 471-482.

Birkel, H. S., Veile, J. W., Müller, J. M., Hartmann, E., \& Voigt, K. I. (2019). Development of a risk framework for Industry 4.0 in the context of sustainability for established manufacturers. Sustainability, 11(2), 384.

Bonekamp, L., \& Sure, M. (2015). Consequences of Industry 4.0 on human labour and work organisation. Journal of Business and Media Psychology, 6(1), 33-40.

Bromiley, P., McShane, M., Nair, A., \& Rustambekov, E. (2015). Enterprise risk management: Review, critique, and research directions. Long range planning, 48(4), 265-276.

Ciocoiu, C. N. (2011). Integrating digital economy and green economy: opportunities for sustainable development. Theoretical and Empirical Researches in Urban Management, 6(1), 33-43.

Coppola, L. (2016). Eighty one percent of the S\&P 500 index companies published corporate sustainability reports in 2015. Flash report. Governance \& Accountability Institute. 
Dangelico, R. M., \& Pujari, D. (2010). Mainstreaming green product innovation: Why and how companies integrate environmental sustainability. Journal of business ethics, 95(3), 471-486.

Dutta, S., \& Lanvin, B. (2019). The Network Readiness Index 2020: Accelerating Digital Transformation in a post-COVID Global Economy. Washington DC: Portulans Institute, WITSA. Retrieved November, 14, 2020.

Ernst \& Young. (2017). Is your nonfinancial performance revealing the true value of your business to investors? Retrieved from: https://assets.ey.com/content/dam/ey-sites/ey-com/en_gl/topics/purpose/purpose-pdfs/eynonfinancial-performance-may-influence-investors.pdf, Accessed on: 14 December 2020.

Eurostat Database available at: https://ec.europa.eu/eurostat/web/main/data/database, Accessed on: 1 December 2020.

Faris, C., Gilbert, B., LeBlanc, B., Ballou, B., \& Heitger, D.L. (2013), Demystifying Sustainability Risk: Integrating the Triple Bottom Line into an Enterprise Risk Management Program, Committee of Sponsoring Organizations of the Treadway Commission.

Forge, S., Blackman, C., Bohlin, E., \& Cave, M. (2009). A Green Knowledge Society. An ICT policy agenda to 2015 for Europe's future knowledge society, A study for the Ministry of Enterprise, Energy and Communications, Government Offices of Sweden, published by SCF Associates Ltd, September 2009.

Ghanbari, A., Laya, A., Alonso-Zarate, J., \& Markendahl, J. (2017). Business development in the Internet of Things: A matter of vertical cooperation. IEEE Communications Magazine, 55(2), 135-141.

Godfrey, P.C., Merrill, G.B., \& Hansen, J.M. (2009). The relationship between corporate social responsibility and shareholder value: an empirical test of the risk management hypothesis. Strategic Management Journal, 30(4), 425- 445.

IISD (2010). The Digital Economy and the Green Economy: Opportunities for strategic synergies. International Institute for Sustainable Development.

Kagermann, H. (2015). Change through digitization-Value creation in the age of Industry 4.0. In Management of permanent change (pp. 23-45). Springer Gabler, Wiesbaden.

Kazancoglu, Y., \& Ozkan-Ozen, Y. D. (2018). Analyzing Workforce 4.0 in the Fourth Industrial Revolution and proposing a road map from operations management perspective with fuzzy DEMATEL. Journal of Enterprise Information Management.

Kiel, D., Müller, J. M., Arnold, C., \& Voigt, K. I. (2017). Sustainable industrial value creation: Benefits and challenges of industry 4.0. International Journal of Innovation Management, 21(08), 1740015.

Liao, Y., Deschamps, F., Loures, E. D. F. R., \& Ramos, L. F. P. (2017). Past, present and future of Industry 4.0-a systematic literature review and research agenda proposal. International journal of production research, 55(12), 3609-3629.

Linkov, I., Trump, B. D., Anklam, E., Berube, D., Boisseasu, P., Cummings, C., ... \& Vermeire, T. (2018). Comparative, collaborative, and integrative risk governance for emerging technologies. Environment Systems and Decisions, 38(2), 170-176.

MacLean, D., Andjelkovic, M., \& Vetter, T. (2007). Internet governance and sustainable development: towards a common agenda.

Müller, J. M., \& Voigt, K. I. (2018). Sustainable industrial value creation in SMEs: A comparison between industry 4.0 and made in China 2025. International Journal of Precision Engineering and ManufacturingGreen Technology, 5(5), 659-670.

Müller, J. M., Kiel, D., \& Voigt, K. I. (2018). What drives the implementation of Industry 4.0? The role of opportunities and challenges in the context of sustainability. Sustainability, 10(1), 247.

NBS Database available at: https://nbs.rs/sr_RS/drugi-nivo-navigacije/statistika/, Accessed on: 14 December 2020

Raj, A., Dwivedi, G., Sharma, A., de Sousa Jabbour, A. B. L., \& Rajak, S. (2020). Barriers to the adoption of industry 4.0 technologies in the manufacturing sector: An inter-country comparative perspective. International Journal of Production Economics, 224, 107546

SORS (2020). Usage of information and communication technologies in the Republic of Serbia. Statistical Office of the Republic of Serbia.

Saardchom, N. (2013). Enterprise Risk Management under Sustainability Platform. Journal of Business and Economics, 4 (1), 32-41.

Schulte, J., \& Hallstedt, S. (2017). Challenges for integrating sustainability in risk management-current state of research. In 21st International Conference on Engineering Design, ICED, Vancouver, Canada, 21 August 2017 through 25 August 2017 (No. DS87-2, pp. 327-336). The Design Society.

Schulte, J., \& Hallstedt, S. I. (2018). Company risk management in light of the sustainability transition. Sustainability, 10(11), 4137 .

Schwab, K. (2017). The fourth industrial revolution. Currency.

Souter, D., MacLean, D., Okoh, B., \& Creech, H. (2010). ICTs, the Internet and Sustainable Development: Towards a new paradigm. International Institute for Sustainable Development, 39.

Stern, N., \& Stern, N. H. (2007). The economics of climate change: the Stern review. Cambridge University press. 
Stulz, R. M. (2008). Risk management failures: What are they and when do they happen?. Journal of Applied Corporate Finance, 20(4), 39-48.

Stock, T., Obenaus, M., Kunz, S., \& Kohl, H. (2018). Industry 4.0 as enabler for a sustainable development: A qualitative assessment of its ecological and social potential. Process Safety and Environmental Protection, 118, 254-267.

Wang, Y., Ma, H. S., Yang, J. H., \& Wang, K. S. (2017). Industry 4.0: A way from mass customization to mass personalization production. Advances in Manufacturing, 5(4), 311-320.

Westerman, G., Bonnet, D., \& McAfee, A. (2014). The nine elements of digital transformation. MIT Sloan Management Review, 55(3), 1-6.

\section{UPRAVLJANJE RIZICIMA ODRŽIVOG RAZVOJA U DIGITALNOJ EKONOMIJI}

Problem održivog razvoja je postao imperativ globalizacije, koji pred preduzeća sve odlučnije postavlja zahtev da posluju društveno odgovorno, odnosno stvaraju vrednost na način koji je održiv u budućem periodu ostvarujući ekonomske, ekološke i društvene ciljeve. Talas promena uslovljen digitalnom transformacijom se smatra mogućnošću, ali i izazovom za ostvarenje koncepta održivog razvoja. Stoga je cilj ovog rada sagledavanje rizika održivog poslovanja, koji proizilaze iz implementacije IKT u proces poslovanja, sa posebnim osvrtom na preduzeća koja posluju u Republici Srbiji.

Ključne reči: rizici održivosti, digitalizacija, upravljanje rizicima, održivi razvoj. 